ГУСАР Л. В., кандидат юридичних наук, доцент кафедри кримінального права (Чернівецький національний університет імені Юрія Федьковича)

УДК 343.95

DOI https://doi.org/10.32842/2078-3736-2019-6-2-18

\title{
ПОНЯТТЯ Й ОЗНАКИ СЕРІЙНИХ ВБИВСТВ
}

Актуальність потреби розробки нового підходу до розуміння поняття серійних вбивств зумовлена неточним визначенням його вітчизняними теоретиками, коли відбувається сплутування понять масових і серійних вбивств, а також стереотипним уявленням, що панує серед працівників правоохоронних органів про особистість серійного вбивці. Формується дане уявлення у результаті акцентування уваги засобів масової інформації лише на типових випадках вчинення серійних вбивств із сексуальних мотивів. Відсутність наукової уваги до проблеми розслідування серійних вбивств зумовлена не стільки незначною кількістю серійних вбивств, що вчиняються на території України, скільки їх високою латентністю як таких, небажанням працівників правоохоронних органів визнавати існування вказаного різновиду вбивств, тим самим не сіяти паніку у суспільстві, уникати резонансності розслідувань, не привертати зайвої уваги до якості своєї роботи, не погіршувати її показники.

Проаналізувавши літературу, пропонуємо таке визначення серійного вбивства: це вчинене 1-єю чи більше особами умисне позбавлення життя 3-ьох чи більше осіб, кожне з яких є окремим епізодом, не пов'язаним з попередньою злочинною діяльністю, відокремленим у часі та місці, однак об'єднаних єдиним (-и) мотивом (ами).

Сформульовані ознаки, які притаманні серійним вбивствам: 1) наявність 3-х чи більше жертв; 2) вчинення одноособово чи групою осіб; 3) значна відокремленість у часі та наявність «періоду охолодження» (тобто повернення злочинця до нормального життя між епізодами); 4) наявність спільного (-их) мотиву (-ів) для злочинів усієї серії; 5) вчинення вбивств серії не пов’язане 3 прихованням попередньої злочинної діяльності; 6) вчинення вбивства має своїм наслідком зняття психологічної напруги у вбивці та отримання задоволення; 7) поступове формування психологічної залежності від протиправної поведінки, а також потреби визнання суспільством своєї винятковості та / чи значимості; 8) особистість жертви, як правило, не є значимою для вбивці, однак у деяких випадках може мати для нього символічне значення; 9) протягом усієї серії вбивств простежується наявність «індивідуального почерку», який може дещо видозмінюватись; 10) не скоєні у зв'язку з військовою службою, політичним тероризмом, організованою злочинністю.

Ключові слова: серійні вбивства, ознаки серійних вбивств, мотиви, серія, множинність, рецидив, повторність, сукупність, багатоепізодність.

Urgency of the need to develop a new approach to understanding of the concept of serial murders is caused by its imprecise definition by Ukrainian authors in this field who sometimes confuse concepts of mass and serial murders as well as by stereotypical image of a serial killer prevailing among law enforcement officials.

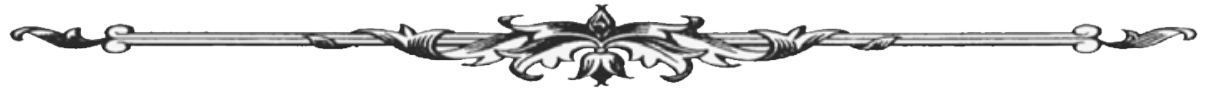


This image is formed as a result of emphasis made by the mass media on typical cases of serial murders committed for sexual motives only. Lack of scientific attention to the problem of serial murders investigation is caused not only by the small number of serial murders committed on the territory of Ukraine, but also by their high latency that is by the unwillingness of law enforcement officials to recognize the existence of the said murder type thereby trying to avoid panic among the public, investigation of high-profile cases, attraction of unnecessary attention to quality of their work, impairment of its performance.

Due to the lack of a unified methodology and/or algorithm for law enforcement actions during investigation of serial murders there is a need to develop and implement one.

Based on the results of the study we suggest the following definition of a serial murder: a deliberate homicide of 3 or more persons committed by 1 or more persons as a separate event not related to the previous unlawful activity, separated in time and place but united by common motive(s).

The following signs characteristic for serial murders were formed: 1) 3 or more victims; 2) committed individually or by a group of persons; 3 ) significant separation in time and existence of "cooling off period" (i.e. return of the offender to a normal life between episodes); 4) existence of common motive(s) for crimes throughout the whole series; 5) serial murders are not aimed at concealment of previous criminal activity; 6) committing a murder has the effect of relieving psychological tension of a killer and having fun; 7) gradual formation of psychological dependence on unlawful behaviour as well as the need for recognition of his / her exclusiveness and / or significance by the society; 8) the victim's personality is usually not significant to the killer; however, in some cases it can have a symbolic meaning; 9) there is a traceable "individual style" throughout the series of murders that may be slightly modified; 10) murders are not committed in connection with military service, political terrorism, organized crime.

Key words: serial murders, signs of serial murders, motives, series, multiplicity, recurrence, repetition, totality, multiple episodes.

Вступ. Серійні вбивства існували здавна, але термін, що використовувався для позначення цього злочину, змінювався протягом століть. У середньовічній Європі жорстоких вбивць наділяли надзвичайними здібностями і вважали надлюдьми. Тоді їх називали не соціопатами і маніяками, а лікантропами (від грец. «lykos» - вовк, «anthropos» - людина) вовками-перевертнями [1, с. 145]. Сьогодні зростає увага суспільства до цих злочинів, про що свідчить широке висвітлення серійних вбивств у засобах масової інформації (далі - ЗМІ), збільшення кількості створених фільмів, які зображують реальних вбивць, котрі $є$ центральними героями картин. Вибух кінематографу відбувся на поч. 1990-х, коли кількість таких стрічок збільшилась від 23-х до більше 150 -ти, і продовжує зростати. Така «популярність» серійних вбивць може спонукати потенційних маніяків, наслідувати інших «відомих» злочинців заради отримання слави.

Статистичні дані про серійні вбивства, вчинені протягом минулих століть, свідчать про значну їх поширеність у США, що може бути результатом високого рівня звітності правоохоронних органів чи збільшення рівня терпимості до жорстокості, що просочилася в Американську масову культуру. Так, у США з XIX ст. до 1990 р. було зафіксовано 105 серійних вбивць, тоді як у Франції цей показник - 11 вбивць, у Німеччині - 17, Великій Британії - 39, Австралії - 10, Канаді - 5, СРСР - 3 серійні вбивці. В інших країнах мали місце лише одиничні випадки виявлених серійних вбивць [2, с. 325]. В Україні відсутня офіційна статистика серійних вбивств, однак наявні офіційні відомості Генеральної Прокуратури України щодо облікованих вбивств двох і більше осіб [3]. Абсолютно правильно, на нашу думку, зазначає В.Н. Ісаєнко, що формування поняття серійних вбивств $є$ однією з основних проблем

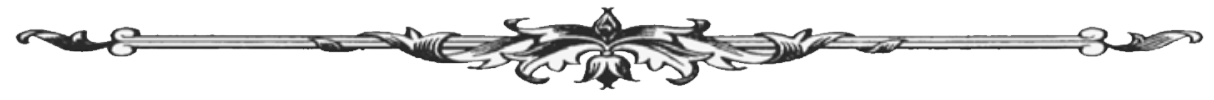


науково-методичного забезпечення діяльності по їх виявленню, розкриттю та розслідуванню. Визначення поняття $є$ неодмінною методичною складовою наукового пізнання будьякого об'єкта, виявлення сутності, розкриття змісту і характерних ознак [4, с. 18].

Постановка завдання. Здійснити аналіз і сформувати поняття й ознаки серійних вбивств.

Окремі проблеми характеристики серійних вбивств відображені у працях таких науковців: Н.А. Аверіної, Ю.М. Антоняна, Р.Г. Ардашева, С.А. Афанасьєва, В.В. Буракова, О.О. Бухановської, О.О. Бухановського, І.Н. Горбулінської, В.Н. Ісаєнко, Н.Н. Китаєва, Д.А. Кирюхин, Н.Ф. Кузнецової, О.Ю. Михайлової, О.І. Скрипнікова, О.Р. Павлова, Ю.М. Самойлова, О.В. Тихонової, І.В. Усанова, А.С. Фоміної, Т.М. Шамонової.

Результати дослідження. Терміни, що використовуються на позначення досліджуваного нами явища, доволі різноманітні. Зустрічаються такі мовленнєві конструкції, як «серійні вбивства», «серійні сексуальні вбивства», «сексуально-садистські вбивства», вбивство із задоволення - «lustmord», серійні (багатоепізодні) сексуальні вбивства.

Приблизно до сер. ХХ ст. у науці стосовно до вбивств, які нині мають назву серійних, використовувалося поняття «множинні» або «багатоепізодні» вбивства, а починаючи 3 70-х pp. XX ст. поняття «серійне вбивство» стало широко використовуватися у ЗМІ та у практиці [5, c. 95]. Уперше термін «serialkiller» був запропонований спеціальним агентом ФБР Робертом Ресслером під час розслідування у Нью-Йорку вбивств, скоєних Девідом Берковіцем [6, с. 2 ].

Визначення поняття серійних вбивств у вітчизняній криміналістичній літературі 3’явилося на початку 90-х рр. Його сформулював Ю.М. Самойлов, як вчинення особою або групою осіб декількох злочинів цього виду, що мають логічний зв'язок: один і той самий об'єкт посягання, мотив, спосіб вчинення [7, с. 60].

Згідно з тлумачним словником української мови «серія - ряд однорідних або споріднених за спільною ознакою предметів чи послідовний ряд яких-небудь дій, подій» [8, с. 1117]. З етимологічного погляду слово «серія» походить від французкого «serie», а першоджерелом є латинське «series»- «ряд», «низка» [5, с. 95].

Поняття серійності тісно пов’ язано з поняттям «множинність», що є вчинення однією особою двох чи більше кримінально караних діянь, які містять ознаки окремих складів злочинів. Множинність проявляється у певних формах: повторність, сукупність і рецидив. Поняття «повторність», відповідно до ч. 1 ст. 32 КК України є вчинення двох або більше злочинів, передбачених тією самою статтею або частиною статті Особливої частини КК України, тобто вчинення тотожних злочинів. Загальне розуміння поняття «серійності» дозволяє віднести її до реальної сукупності злочинів, оскільки часто вбивства, що складають серію, можуть бути кваліфіковані за різними частинами ст. 115 КК України [9, с. 131].

Терміни «сукупність» і «рецидив» ще більш змістовно-віддалені від визначуваного нами поняття, оскільки «сукупність» застосовується при акцентуванні уваги на групі різнорідних злочинів, а другий своєю сутнісною ознакою має попереднє засудження особи. Також варто звернути увагу на ще одне суміжне поняття - «багатоепізодність». Правоохоронні та судові органи оперують цим поняттям, а також воно вживається у нормативних актах MBC, однак законодавчо сутність поняття не визначена. Епізод слід розуміти як обмежений у місці, часі, ситуації самостійний акт завершеної або незавершеної кримінальної довільної (вольової) поведінки. Багатоепізодність передбачає наявність не менше 2-х злочинних актів, кожен з яких може включати декілька складів злочинів.

Основною ознакою, що відрізняє серійне та багатоепізодне вбивство між собою є відносна однорідність криміналістичних ознак злочинів, що складають окремі епізоди. Ми підтримуємо думки О.Ю. Михайлової, С.Б. Целіковского, які вважають, що багатоепізодне вбивство включає у себе цілий ряд дуже різних за правовими і психологічними характеристиками діянь, наприклад, вбивства свідків або співучасників раніше скоєного злочину і т. д. Серійні ж вбивства відрізняються від багатоепізодних цілим рядом ознак, а саме: 1) найчастіше окремі епізоди у таких вбивствах вчиняються з різними мотивами та носять різний психологічний зміст для винного, тоді як багатоепізодні вбивства об'єднані єдиною злочинною

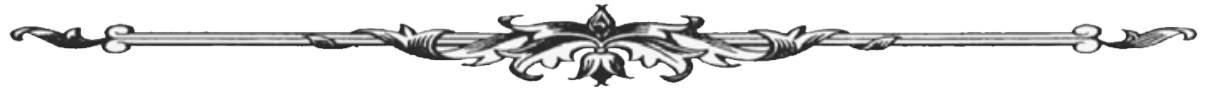


метою, і навіть при наявності розриву у часі повинні кваліфікуватись за п. 1 ч. 2 ст. 115 КК України. При вчиненні серійних вбивств, навіть коли злочини вчиняються на основі схожої мотивації у злочинця зберігається персоніфіковане ставлення до кожного злочинного акту; 2) у багатоепізодних вбивствах відсутні ознаки стереотипності та ритуальності агресивної поведінки. Єдність мотивації та деперсоніфікація жертви визначають реалізацію одного і того ж стереотипу поведінки у різних епізодах серійних злочинів [10, с. 40-41].

Таким чином, сутнісна відмінність між серійними та іншими багатоепізодними вбивствами полягає у відмінності умислу. При вчиненні конкретних епізодів серійних вбивств у свідомості злочинця не існує наміру вчинити конкретну кількість вбивств, а умисел на вчинення наступного виникає після вчинення попереднього. У той же час поняття «багатоепізодність» співвідноситься 3 поняттям «серійність» як загальне з окремим, «серійність»$€$ одним із різновидів багатоепізодності.

Серійні вбивства у вітчизняній правовій науці часто розглядаються виключно як такі, що мають сексуальне підгрунтя. О.Н. Кузнєцова вважає, що для серійних вбивств характерна певна мотивація (головним чином $з$ яскраво вираженим сексуальним забарвленням) [11, с. 149]. Можна припустити, що специфіка такого «сексуально-мотиваційного» підходу до визначення поняття серійних вбивств пояснюється відсутністю достатньої об'єктивної інформації про інші типи серійних вбивць, окрім сексуальних маніяків.

Науковці також включають до визначення поняття серійного вбивства таку ознаку, як «вчинення в умовах неочевидності» (А.О. Бухановський [12]). Так, ця характеристика може відображати специфіку первинної слідчої ситуації, однак згодом можуть бути встановлені свідки подій. Безсумнівним є факт, що розслідування серійних вбивств пов'язано з браком криміналістичної інформації, у т.ч. показань свідків чи потерпілих, та частим здійсненням підозрюваним дій по прихованню слідів злочину. Дана обставина є характеристикою обстановки вчинення серійних вбивств, однак не визначальною ознакою для диференціювання їх від інших видів злочинів.

Інші науковці визначають серійні вбивства через єдність мотивів, способів вчинення. Наприклад, І.Н. Горбулінська, визначає серійні вбивства як вчинені різночасно два та більше вбивства, що характеризуються схожістю мотиву, часом, місцем і обстановкою злочинів, однотипністю способів вчинення і приховування злочинів, збігом характеристик загиблих осіб та іншими ознаками, що дають достатні підстави для висунення версії про вчинення злочинів однією особою $[13$, с. 8]. Тут робиться акцент на «автографі» («signature») вбивці, під яким розуміються «дії, необхідні для вчинення злочину, у вчиненні яких злочинець відчуває потребу» [14, с. 271-272]. На нашу думку, виділення такої специфічної ознаки, як однотипність жертв, не притаманна усім видам серійних злочинців. Також «почерк» серійного вбивці може змінюватися з часом. Логічною буде характеристика серійних вбивств, як злочинів, що становлять окремі епізоди (події злочину), кожному з яких притаманні власні ознаки складу злочину (обстановки, місця, часу), що нерідко можуть збігатись, однак формальна відсутність будь-якої з них не повинна впливати на характеристику цих епізодів як cepiï.

Виділення такої процесуальної ознаки як «достатності підстав для висунення версії про вчинення злочинів однією особою», на нашу думку, є формальним, оскільки ця ознака серійних вбивств не є сутнісною та не дозволяє відмежувати їх від інших видів множинності злочинців.

Масові та серійні вбивства мають безліч подібних рис, наприклад: жертвами переважно є випадкові особи (тобто між злочинцем і потерпілим немає особистих зв`язків), а злочинці страждають від розладів психіки, i, як і серійні вбивці, нерідко переживали дитячі травми [15, с. 289]. Масові вбивства призводять до більшої кількості жертв, ніж серійні (Джефрі Дамер, наприклад, вбив 17 осіб). Хоча і масові, і серійні вбивства викликають страх і тривогу у суспільстві, реакція на масові вбивства є більш локалізованою. Справа у тому, що ми схильні сприймати масове вбивство як більш зрозуміле, більш «людське» явище: неконтрольований вибух емоцій особистості.

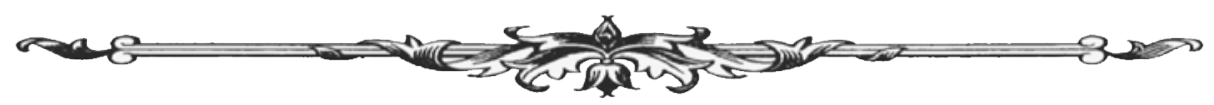


Під «massmurder» (масовим вбивством) розуміється вбивство 4-ьох і більше людей, що сталося в одному місці. Виділяють 2 типи масових вбивць: людина, чиї проблеми зросли до такої міри, що вона діє проти випадкових людей, через сплеск жорстокості. Другий тип «сімейні» масові вбивці, жертвами яких стають члени сім’ї [16, с. 96].

Відмінність між масовим і серійним вбивством проявляється у просторово-часових характеристиках, вибірковості жертв, знаряддях і мотивах. Масовий вбивця зазвичай використовує вогнепальну зброю для встановлення психологічного бар'єру між ним і жертвою, керується корисливим мотивом і мотивом помсти, вбиває 3 невеликим проміжком часу в одному місці, тоді як серійні вбивства мають зовсім інші криміналістичні характеристики, які будуть висвітлені нижче.

У багатьох іноземних державах взагалі не закріплено поняття серійного вбивства (наприклад, у Кримінальному кодексі Австралії 1995 р. [17]., Франції 1992 р. [18]). У ч. 2 ст. 211 Кримінальному кодексі Німеччини встановлено, що карається довічним позбавленням волі вбивство людини, зокрема з садистських мотивів чи для задоволення сексуального потягу[19]. У першому випадку вбивство людини саме по собі приносить задоволення і є ціллю злочинного діяння, а друге своєю ціллю має вчинення сексуальних дій.

Дискусійним серед науковців є питання щодо кількості вбивств, що є важливим для визнання серії. Ця кількість різниться від двох до десяти [20, с. 326]. NCAVC наводить дані, про те, що 60,9\% серійний вбивць посягали на життя від 2 до 4-х жертв, а число випадків, коли жертв було більше, ніж 10, складає 12,0\% від загальної кількості вчинених серійних вбивств [21, с. 17].

Федеральний закон США «Захист дітей від сексуального насилля» 1998 р. визначає серійне вбивство, як: 3 чи більше вбивства, не менш як одне 3 яких було вчинено на теритоpiї США, які мають загальні риси, що дозволяє припускати вчинення їх однією особою чи особами [22].

На симпозіумі у Сан Антоніо науковці дійшли згоди, що серійні вбивства повинні володіти наступними ознаками: 1) вчинено однією чи більше особами; 2) наявні дві чи більше жертви; 3) події були окремими інцидентами, що стались у різний час [23, с. 9].

Цікавими є міркуваннями Джонні Моузос і Девіда Веста 3 Австралійської асоціації кримінології, які підкреслюють таку проблему: вбивця, який вчинив лише два гоміциди (лат. homicide - вбивство) і затримується поліцією, не буде вважатися серійним і піддаватиметься слабшому кримінально-правовому впливу, хоча мотивація та суспільна небезпечність його буде така сама, як і того, який вбив п’ятьох [24]. 3 цією думкою не можна не погодитися, однак варто вважати сутнісною рисою, що відрізняє вбивство двох і більше осіб і серійне вбивство, таку як здійснення останнього на постійній основі, тобто систематично. Згідно з п. 10 Постанови Пленуму Верховного Суду України від 24 жовтня 2003 р. № 7 у контексті вирішення питання про скасування звільнення від відбування покарання з випробуванням, систематичним вчиненням адміністративних правопорушень вважається вчинення три і більше діянь[25]. Тому вважаємо, що серійним повинно вважатись вбивство трьох і більше осіб, оскільки таким чином здійснюється відмежування від вбивства двох і більше осіб, що передбачене у п. 1 ч. 2 ст. 115 КК України, яке володіє меншою суспільною небезпекою та за яке передбачене альтернативне основне покарання у виді позбавлення волі від 10 до 15 років або довічного позбавлення волі. На нашу думку, санкція за вчинення серійних вбивств повинна бути безальтернативною у вигляді довічного позбавлення волі, зважаючи на надзвичайну суспільно небезпечність цих злочинів.

Серійні вбивства не вчиняються лише одноособово. Ці злочини становлять підвищену суспільну небезпеку, так як дії двох і більше злочинців полегшують досягнення злочинного результату, дають можливість легше приховати сліди злочину. Ерік Хіккі ж констатує, що кожне 4-те серійне вбивство вчиняється у співучасті [26, с. 6]. Причому серійні вбивства у парах можуть вчинятися як 2-ма жінками чи чоловіками, а також чоловіком і жінкою. Отіс Тул і Генрі Лукас вбили заради задоволення більше 600 осіб. Тул був гомосексуалістом, Лукас - бісексуалом і садистом. Сексуально мотивовані вбивства можуть бути вчинені не лише чоловіками, а і сімейними парами - Геральд і Шарлін Галего, які вбивали неповнолітніх, перед тим тримаючи їх у сексуальному рабстві [27, с. 47-48]. У таких парах зазвичай

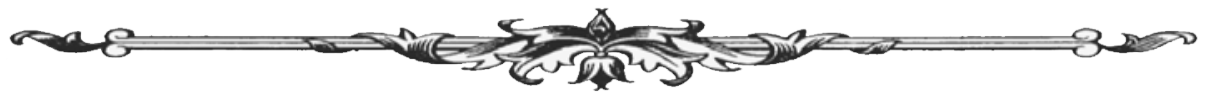


є домінантна особистість із садистськими схильностями, зазвичай чоловік, а жінка ж боїться партнера та допомагає йому вчиняти вбивства.

На нашу думку, мотив, є сутнісною характеристикою злочину та без його з'ясування неможливе розуміння серійних вбивств як діянь, що умисно вчиняються людиною. Типовою вважається така мотивація серійного вбивці як сексуальне задоволення або внутрішнє психологічне задоволення [28, с. 326]. Інші дослідники стверджують, що серійні вбивці діють 3 потребою протиставити себе суспільству, в якому вони почуваються безпорадними [27, с. 289-290]. Для усіх серійних вбивць характерно знеособлення жертви, іï особистість не має жодного значення для вбивці. Навіть тоді коли вбивця «полює» на певний тип жертв, для нього важливою $\epsilon$ лише особистість, яку символізують потерпілі. Попереднє знайомство з жертвою має нетривалий характер і не встановлює тісних особистісних зв'язків між ними. Тому випадки вчинення вбивств із мотивів ревнощів, образи, помсти чи на іншій особистій основі не стосуються досліджуваної категорії вбивств. Наприклад, особа, що ненавидить повій, вважає їх дії аморальними й очищує від них світ кардинально відрізняється від того, хто вбиває за зраду, навіть неодноразово протягом певного часу. Помітно, що обома керувало почуття ненависті, однак перший сприймав жертв знеособлено, i їх вбивство приносило йому задоволення або не суперечило його системі цінностей, тоді як останнього із жертвою пов’ язували особисті стосунки.

Можна стверджувати, що діями злочинця керує почуття влади, однак все ж найбільш загальним є гедоністичний мотив, тобто прагнення отримання задоволення, що при вчиненні серійних вбивств пов'язано із спогляданнями страждань жертв, відчуттям влади над людським життям, власної унікальності й особливості, нездоланності.

Висновки. В Україні та у багатьох іноземних державах законодавчо поняття серійне вбивство не закріплено, хоч і вживається на практиці. Подібний висновок підтверджує необхідність розробки цього поняття та єдності розуміння сутності серійних вбивств. Загальним у поглядах науковців є те, що «серійність» вбивств означає, що вони скоєні послідовно, з певним проміжком у часі, певною особою, у разі збігу мотиву, мети, способу вчинення.

Проаналізувавши проаналізовану літературу, пропонуємо таке визначення серійного вбивства: це вчинене 1-єю чи більше особами умисне позбавлення життя 3-ьох чи більше осіб, кожне з яких є окремим епізодом, не пов'язаним з попередньою злочинною діяльністю, відокремленим у часі та місці, однак об’єднаних єдиним(-и) мотивом(-ами).

Сформульовані ознаки, які притаманні серійним вбивствам: 1) наявність 3-х чи більше жертв; 2) вчинення одноособово чи групою осіб; 3) значна відокремленість у часі та наявність «періоду охолодження» (тобто повернення злочинця до нормального життя між епізодами); 4) наявність спільного (-их) мотиву (-ів) для злочинів усієї серії; 5) вчинення вбивств серії не пов'язане з прихованням попередньої злочинної діяльності; 6) вчинення вбивства має своїм наслідком зняття психологічної напруги у вбивці та отримання задоволення; 7) поступове формування психологічної залежності від протиправної поведінки, а також потреби визнання суспільством своєї винятковості та / чи значимості; 8) особистість жертви, як правило, не є значимою для вбивці, однак у деяких випадках може мати для нього символічне значення; 9) протягом усієї серії вбивств простежується наявність «індивідуального почерку», який може дещо видозмінюватись; 10) не скоєні у зв'язку з військовою службою, політичним тероризмом, організованою злочинністю.

\section{Список використаних джерел:}

1. Шехтер Е. Энциклопедия серийных убийств / перевод с англ. О. Блейз. Москва : КРОН-ПРЕСС, 1998. С. 145.

2. Warf B. Heinous spaces, perfidious places: the sinister landscapes of serial killers. Social \& Cultural Geography. 2002. Vol. 3. № 3. P. 325.

3. Статистична інформація за 2017 та 2018 роки. Про зареєстровані кримінальні правопорушення та результати їх досудового розслідування. URL: www.gp.gov.ua/ua/stat.html.

4. Исаенко В.Н. Проблемы теории и практики расследования серийных убийств : дис. ... докт. юрид. наук : 12.00.09. Москва, 2005. С. 18.

5. Крюкова Е.С. Криминалистический взгляд на понятие серийное убийство. Юридический вестник Дагестанского государственного университета. 2013. № 2. С. 95.

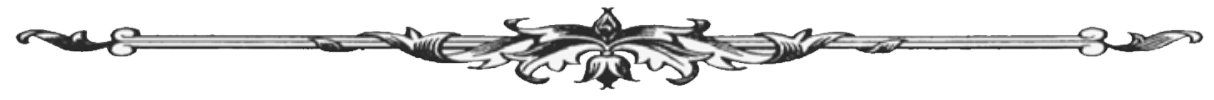


6. MillerL. Serialkillers: I. Subtypes, patterns, andmotives. Aggression and Violent Behavior. 2014. P. 2.

7. Самойлов Ю.М. Организация работы правоохранительных органов по раскрытию серийных убийств. Расследование убийств в зарубежных странах : сборник статей. Москва : Изд-во ВНИИ МВД, 1991. С. 60.

8. Великий тлумачний словник сучасної української мови / уклад. і голов. ред. В.Т. Бусел. Київ - Ірпінь : ВТФ «Перун», 2004. С. 1117.

9. Кримінальний кодекс України від 05 квітня 2001 р. № 2341-III. Відомості Верховної Ради Украӥни. 2001. № 25-26. Ст. 131.

10.Михайлова О.Ю. Судебно-психологическая експертиза личности серийных сексуальных преступников. Москва : КРЕДО, 2008. С. 40-41

11. Кузнецова О.Н. Роль адвоката в защите лиц, совершивших серийные убийства. Серийные убийства и соичиальная агрессия : Материалы 2-й международной научной конференции. Ростов-на-Дону, 1998. С. 149.

12.БухановскийА.О.Психическиерасстройстваусерийныхсексуальныхпреступников. Аналитический обзор 2003. URL: http://www.studfiles.ru/preview/2143954/page:2/\#2143954.

13. Горбулинская И.Н. Использование специальных познаний в процессе расследования серийных убийств: первоначальный этап расследования : автореф. ... дис. канд. юрид. наук : 12.00.09. Барнаул, 2007. С. 8.

14. Дуглас Д. Охотники за умами: ФБР против серийных убийц / пер. с англ. А. Соколова. Москва, 1998. С. 271-272.

15. Meloy J. Introduction to this Issue: Serial and Mass Homicide. Behavioral Sciences and the Law. 2004. № 22. P. 289.

16. Douglas J. Crime classification manual: a standard system for investigating and classifying violent crime. San Francisco, Calif.: Jossey-Bass 2006. P. 437. URL: http://www.murders.ru/ Classific.pdf.

17. Criminal Code Act 1995№ 12, 1995. Australian Government. Comlaw. URL: http://www.comlaw.gov.au/Details/C2015C00254.

18. Criminal Code of the French Republic 1992 (2005) (English version). URL: http://www.legislationline.org/documents/section/criminal-codes.

19. German Criminal code (Strafgesetzbuch, StGB) 13 November 1998. URL: http://www.gesetze-im-internet.de/englisch_stgb/index.html.

20.Kraemer G. Comparing Single and Serial Homicide Offenses. Behavioral Sciences and the Law. 2004. № 22. C. 326.

21. Morton R. Serial Murder: Pathways for investigations. US FBI. P. 17.

22. Public law 105-314-OCT. 30, 1998 Protection of children from sexual predators Title 18, United States Code. URL: http:/www.gpo.gov/fdsys/pkg/ PLAW-105publ314/pdf/PLAW105publ314.pdf.

23. Serial Murder. Multi-Disciplinary Perspectives for Investigators. National Center for the Analysis of Violent Crime (FBI). P. 9. URL: http://www.fbi.gov/stats-services/publications/ serial-murder.

24. Mouzos J. An examination of serial murder in Australia. Australian Institute of Criminology. Trends \& Issues in crime and criminal justice. 2007. URL: http://aic.gov.au/ media_library/publications/tandi_pdf/tandi346.pdf.

25.Про практику призначення судами кримінального покарання: Постанова Пленуму Верховного Суду України від 24 жовтня 2003 р. № 7. URL: http://www.scourt.gov.ua/clients/vs. nsf/0/2B7E0AAF30853651C3256DF7002 E9A19Open.

26. Hickey E. Serial Murderers and Their Victims. Wadsworth, Cengage Learning, 2013. C. 6. URL: https://www.cengagebrain.com.mx/content/ 9781285283807.pdf.

27. Holmes R. Serial murder. USA: Sage publications, 2010. P. 47-48.

28. Kraemer G. Comparing Single and Serial Homicide Offenses. Behavioral Sciences and the Law. 2004. № 22. P. 326.

29.Ferguson C.J. Defining and classifying serial murder in the context of perpetrator motivation. Journal of Criminal Justice. 2003. № 31. P. 289-290.

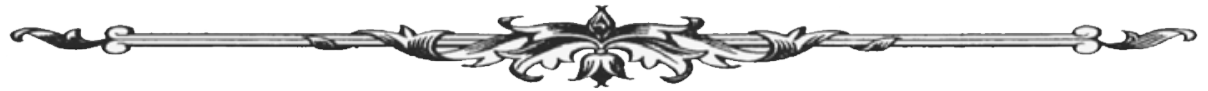

